\title{
Slippery Geographies of the Urban and the Rural: Public Sector LGBT Equalities Work in the Shadow
} of the 'Gay Capital'

\begin{abstract}
$\underline{\text { Abstract }}$
The implementation of lesbian, gay, bisexual and trans (LGBT) equalities is not uniform, but varies locally and regionally as well as nationally. Research has long focused on large metropolises, with the assumption that work to improve LGBT equalities will mostly take place in these areas. However, a growing body of geographic research attests to positive LGBT experiences in rural areas, and calls for further attention to LGBT lives and equalities in hitherto neglected towns. In this paper I detail public sector LGBT equalities work which occurred in the areas of Hastings, Rother and wider East Sussex, through a Participatory Action Research (PAR) project involving a partnership of local public services, LGBT communities, activists and academics from 2010 to 2013. I aim to show that public sector LGBT equalities work is intimately connected with a relational logic of rural/urban, and that this logic can result in some areas being overlooked when it comes to public sector LGBT equalities. Bringing a burgeoning literature on geographies of LGBT equalities together with rural geographies, I advance discussions of progressive public sector equalities work beyond the urban and explore how relational geographies of 'the rural' and 'the urban' might come together with the discourses of public sector equalities work. Acknowledging the continued importance of discursive rural/urban binaries with regard to LGBT equalities in neglected rural areas, I also explore the slippery ways in which such imaginaries adhere and do not adhere to particular areas. These slippery geographies can result in areas being overlooked in terms of LGBT equalities work. Finally, I point out the importance of other alternative geographic imaginaries relevant to LGBT lives and communities which rural/urban binaries may render less visible. In doing so, this paper, explores the complex relational geographies of how the urban and the rural emerge through discourses of public sector LGBT equalities.
\end{abstract}

\section{Key Words}

Rural, urban, LGBT, sexuality, equality, imaginaries, public sector, relational

\section{Introduction}


Definitions of the rural are highly contested (Bryant \& Pini 2011; Gallent et al 2008; Halfacree 2004; Holloway \& Kneafsey 2004; Woodward \& Halfacree 2002:74-76), to the point where when 'the rural' is discussed it is not always clear what is meant (Bryant \& Pini 2011). Some scholars consequently questioned the continued relevance and usefulness of 'the rural' as an object of analysis (see Champion \& Hugo 2004; Hoggart 1990; Woods 2012). This has been an abiding question in rural geography and other rural studies, but one to which writers have responded by positively asserting the importance of rurality (Halfacree 2004; Marsden 2006:4; Phillips \& Williams 1984:2-3). As Halfacree has argued, 'in spite of receiving a battering from numerous commentators... [the rural] does not simply go away. Indeed, its social and cultural significance today may be as great as it has ever been' (Halfacree 2004:285) and most particularly in the realm of social differences (Cloke 2006a:19). Cloke's assertion is evidenced particularly clearly with regard to sexual and gender identities, as many studies demonstrate lesbian, gay, bisexual and transgender (LGBT) people actively constructing their everyday lives through rurality and a counterposed urbanity (see for example Bell 2000; Browne 2011; Comerford et al 2004; Kazyak 2011; Kirkey \& Forsyth 2001; Knopp 1998; Soderstrom 2010). In this paper I engage with both these scholarly contestations of the rural, and LGBT people's associations with it, through a focus on public sector work on LGBT equalities in the UK. Underpinning this paper is a question about how geographies of the rural and the urban relate to LGBT equalities, particularly in the UK in the wake of the Equality Act 2010. In answering this question, I aim to show first that the discourses and practices of public sector LGBT equalities work are intimately connected with binary rural/urban logics, and are co-constituted via relational geographies of LGBT equalities. Arguing that these relationally-produced urbans and rurals can result in some areas being over looked when it comes to public sector LGBT equalities, my second aim is to highlight other geographic imaginaries which, when analysed alongside those of the rural and the urban, may allow for a fuller study of local geographies of LGBT equalities.

My engagement with the rural utilises the relational poststructural approach to space and place developed by writers such as the late Doreen Massey (2005). Massey argued in favour of a 
conception of spatiality 'as relative (defined in terms of the entities 'within' it), relational (as constituted through the operation of social relations, through which the 'entities' are also constituted) and integral to the constitution of the entities themselves (the entities are local timespaces)' (Massey 1999:262; see also Doel 1999; Massey 2005; Murdoch 2006). This relational approach, then, understands rural space to be both produced (in part) by and productive (if not wholly) of material and discursive relations (Heley \& Jones 2012) through which perceived spatialities can shift and overlap with one another (Rose 1993; Gregson \& Rose 2000). As Heley and Jones put it, relational geographies involve 'an increasing recognition of the intertwined and coconstituent production of rural space through material and discursive phenomenon, processes and practices' (Heley \& Jones 2012:209; see also Massey 2005; Woods 2011:265-294). Furthermore, building on Woods (2012) in acknowledging that 'the urban' and 'the rural' cannot be easily defined or fixed to specific and bounded physical areas, I incorporate a wide variety of spaces and geographies within my research. These include areas, spaces and population centres which do not fit easily or comfortably into either 'urban' or 'rural' and those which align more strongly with other geographic imaginaries relevant regarding sexuality and gender identity such as the 'small town' (Whittier 1997), the 'seaside resort' (Hemingway 2006) or more specific imaginaries such as the 'Gay Capital' regarding the small UK city of Brighton \& Hove (Browne \& Bakshi 2013). Although common, such geographic areas and associated imaginaries are often overlooked by geographic research surrounding LGBT lives in favour of large cities (Brown 2008). Through their inclusion I aim to simultaneously highlight and challenge the centrality and normalisation of the urban in LGBT research - Halberstam's 'metronormativity' (2005) - as well as the role of a rural/urban dynamic in contributing to their neglect in geographic research. I utilise and develop the insights of Woodward \& Halfacree (2002), who argue that understanding rurality to be multiple and fluid can open up new and important ways of understanding geographic politics (ibid. 84) - a 'politics of the rural' (Woods 2006). I highlight how 'the rural', 'the urban' and other geographic imaginaries come to be mobilised in public sector LGBT equalities work and what politics this may enable or neglect. 
Much work on relational geographies, including relational rurals, explores relations between the 'local' and the 'global' (Amin 2004; Heley \& Jones 2012; Massey 2004; Massey 2005; see Jones 2009 for a critique of this approach). My work instead examines relational rurals and urbans in a much smaller context. It builds upon findings from a Participatory Action Research project called 'LGBT Equalities in Hastings, Rother \& East Sussex'. This project took place in the South East region of England from 2010 to 2013 and was twinned with my PhD thesis 'In the Shadow of the Gay Capital'. The aim of this thesis was to explore how public sector LGBT equalities were being produced and implemented in East Sussex, and consequently in this paper I focus specifically on the question of how rural/urban logics relate to LGBT equalities in the contemporary UK. Using the mixed-methods data gathered as part of this project I address important developments in rural geographies and the growing field of geographies of sexualities in a number of key ways.

First, while acknowledging that binary categories of 'urban' and 'rural' are a frequently-deployed and important discursive approach through which public sector workers and LGBT people beyond the urban metropolis understand and organise LGBT equalities, I argue that public sector LGBT equalities work in East Sussex complicates easy distinctions between urban and rural. I demonstrate that within the context of the LGBT Equalities in Hastings, Rother \& East Sussex project, specific urban and rural geographies operate relationally (Massey 2005; Heley \& Jones 2012) to construct one another through discourses of public sector LGBT equalities. Per poststructural theories of space and place (Doel 1999; Gregson \& Rose 2000; Murdoch 2006), these relational geographies structure the ways in which LGBT lives are understood within public sector equalities work and by LGBT people themselves (Valentine 2002). I make this point by exploring LGBT boundary crossings within and beyond East Sussex and Brighton \& Hove; and then by analysing public sector LGBT equalities discourse from meetings of the LGBT equalities project. Martin Jones has critiqued relational thinking as potentially overlooking the ongoing significance of regions, scales and places (Jones 2009). Mindful of this critique, I argue that these slippery relational constructions may make it harder for us to recognise and engage with LBGT lives focused in areas which do not fall comfortably 
into either primarily 'rural' or primarily 'urban', which are often elided from research or too quickly folded into broader urban/rural categories. Therefore while the urban/rural dynamic clearly remains important for LGBT equalities, my work offers a vital critique of its unquestioned dominance. In keeping with this, the final section of my argument suggests that these other, relatively neglected geographies of LGBT lives and communities could be productively explored through (in the case of East Sussex and Brighton \& Hove) other geographic imaginaries such as the 'gay capital' and the 'small town', as well as by attending to the geographic specificities and complexities of the areas in question. In this way I hope to show what careful attention to a multitude of relational geographies at the 'local' scale can offer in progressing LGBT equalities in rural areas.

\section{Rural Geographies of Sexualities and LGBT Equalities}

DuPuis has argued that who gets to live in rural space, who is imagined to fit, and what they do there, are key ways in which the rural is constructed (DuPuis 2006:129). This manifests through the discursive and material inclusions and exclusions of a diverse array of rural 'Others' regarding a supposedly 'gemeinschaft' rural community linked with stability and closeness (Cloke 2006a; see also Parr et al 2004; Philo 1992; Roche 2002; Sibley 2006; Woods 2011:173-175; Woodward \& Halfacree 2002:81). Geographers of sexualities have been increasingly critically engaged with the complexities of these inclusions and exclusions. Historically, geographical studies of sexualities have focused on metropolitan urban centres (Bell \& Valentine 1995a; Brown 2008; Gorman-Murray et al 2012; Kirkey \& Forsyth 2001:423; Lindhorst 1997; Tongson 2011), joined to an implicit teleology of lesbian and gay identity development through the supposedly overwhelming rural to urban migration pattern of sexual minorities (Herring 2007:344; Weston 1995). Indeed particularly with regard to gay men, the city itself has been said to be key to gay identity formation and community development (Bech 1997; Aldrich 2004). Jack Halberstam (2005) has provided a key critical intervention in LGBT geographies through his identification of an overarching 'metronormativity' in 
research on LGBT lives and, developing this, Gavin Brown (2008) has called for more engagement with LGBT life in 'ordinary' cities and towns beyond the urban metropolis. My own research responds to both of these points, as can be seen through the geographic scope outlined in the following Section 3.

With regard to the experiences of LGBT people in rural areas, geographers have previously explored the troubled and secretive lives of rural lesbians and gay men, in which a repressive rurality polices gender roles and sexualities and results in social difficulties for the non-heterosexual (Bell \& Valentine 1995a; Bell \& Valentine 1995b; Bowen 2005; Comerford et al 2004; D'Augelli 2006; Fenge \& Jones 2012; Kramer 1995; Lindhorst 1997; Little 2003:373; Oswald \& Culton 2003:72; Smith 1997), and constricts the development of a 'true' (and implicitly urban) gay/lesbian identity (Kramer 1995; Howard 1999). Geographic literature on sexuality regularly refers to particular features of the urban and the rural which are seen to be of significance with regard to LGBT lives, with the urban/rural dynamic functioning to organise such features as existing in one area and not the other. For instance, writers note a common connection made between urban and city space and features such as anonymity (Annes and Redlin 2012; Bell and Valentine 1995a; Kennedy 2010:1059; Kirkey and Forsyth 2001; Valentine and Skelton 2003), safety and tolerance of LGBT expression (GormanMurray 2009; Hanhardt 2013; Kennedy 2010:1074), the existence and development of LGBT identities and communities (Herring 2007:344-345; Doderer 2011; Kramer 1995; Brown 2009; Johnston \& Longhurst 2009; Gray 2009; Kazyak 2011; Lindhorst 1997; Gorman-Murray 2007; Bell \& Valentine 1995a; Annes \& Redlin 2012; Smith 1997:16; Valentine \& Skelton 2003:849) and access to LGBT-focused and LGBT-friendly public services (Gray 2009:5; Lindhorst 1997). Conversely, rural space is commonly imagined to lack such features or to exhibit their opposite. Even the most positive of research detailing sexual minorities in rural areas still indicate recurring issues related to access to services, contested feelings of community (both lesbian/gay and the wider rural community), isolation, and lack of information (Comerford et al 2004; Fenge \& Jones 2012; Friedman 1997; Haag \& Chang 1997; Kennedy 2010; Kirkey \& Forsyth 2001; Lindhorst 1997; Smith 1997). The 
literature surrounding LGBT equalities is focused primarily on sexual minorities such as lesbians and gay men - literature specifically engaging with bisexual or trans lives and ruralities seems almost entirely absent (though see Halberstam 2005 and Abelson 2016).

Recent scholarship, however, increasingly calls into question the idea that all rural spaces are intolerant, isolating and sites of anxiety for sexual minorities (Anderson et al 2015). A number of studies now point to sexual minorities' positive experiences in rural spaces and the ways in which particular rural imaginings - such as those relating to nature, simplicity, friendliness and being quiet are used to construct the rural as a site of acceptance, alternative identity construction and community (Gray 2009; Herring 2007; Kazyak 2011; Kennedy 2010; Kirkey \& Forsyth 2001; Smith \& Holt 2004; Soderstrom 2010; Whittier 1997). Indeed work from Eastern Europe suggests that here it is urban areas which are understood to be sites of particular intolerance and violence towards LGBT people (Kuhar \& Švab 2013), attesting to the importance of geographically specific research. Similarly, while the importance of 'natural' heterosexualities and the disavowal of sexual 'others' in the construction and representation of rural idylls has been noted (Bell 2006; Cloke 2003), a body of work has also explored homosexual and lesbian and gay rural idylls (Bell 2000; Bell \& Valentine 1995a; Gorman-Murray et al 2012; Herring 2007; Kirkey \& Forsyth 2001). Here rural idylls can be constructed to include and valorise homosexuality and lesbian and gay identities, drawing on ideas such as essential womanhood, nature, the primitive and the spiritual (Anlin 1989; Bell \& Valentine 1995a:8; Bell 2000; Bell 2006; Gorman-Murray et al 2012; Herring 2007).

Some writers have already pointed out the importance of this perceived rural/urban opposition with regard to the discursive and material construction of each, even without considering elements of sexuality (Cloke 2006a:18; Lapping 2006:104; Phillips \& Williams 1984:11-13; Woods 2011). As Woods points out (Woods 2007:502), this is not to say that the urban is simply 'overlapping' the rural or dominating the rural. Rather, the discursive dyad of urban/rural simultaneously blurs and produces each in a variety of specific ways through the inference of difference and opposition to the 
other (Cloke 2006b:19; Lacour \& Puissant 2007; Woods 2011:43-47). Relationships between 'the rural' and 'the urban' appear highly important regarding the ways in which sexual minorities such as lesbians and gay men frame their experiences in rural spaces (Bell \& Valentine 1995a:120; Kennedy 2010). At a pragmatic level this can be related to the desire or need to access cities and urban spaces for their particular services or to 'reconnect' with lesbian and gay communities (Gorman-Murray et al 2012; Kennedy 2010; Kirkey \& Forsyth 2001; Smith \& Holt 2004). Scholars have shown how sexual minorities living in rural areas deploy discourses which stereotype those in urban areas, constructing their own rural identities in opposition (Cody \& Welch 1997; Herring 2007; Kazyak 2011; Kennedy 2010:1078-1079; Kirkey \& Forsyth 2001; Soderstrom 2010; Whittier 1997). Kazyak, for example, shows how her participants set up oppositions between being both 'boring' and 'settled' within an intimate (rural) community, in contrast with the undesirable excitement and change of an anonymous (urban) community (Kazyak 2011:570). Indeed, contra work which asserts the intolerant attitudes of rural residents (Kramer 1995; Lindhorst 1997; D’Augelli 2006), Kazyak's participants invert the urban/rural binary through attitudes towards sexuality. The rural, through all members of the community knowing one another while not acknowledging sexual difference, becomes a space of tolerance, while the city, through interpersonal anonymity and openness of sexual difference, becomes a space of potential homophobic danger (Kazyak 2011:574-575; see also Kuhar \& Švab 2013). Similarly, Bell has described how male rural sexual subjects are fetishized by some urban gay men through the use of an urban/rural dynamic which constructs the rural as a site of desirable masculinity versus urban effeminacy (Bell 2000; see also Fellows 1996). Therefore we can see that the imagined constructions of urban and rural spaces, and the relationships between them, are complex but also allow for productive reimaginings of supposedly negative rural sexual subjectivities. However the stereotypification of urban subjects and the potentially exploitative fetishisation noted by Bell (2000) should act as a reminder not to accept this as necessarily or entirely progressive. 
Rural and urban constructions, then, are crucially related to sexualities and sexual identities. Building on the insights of Massey (1999) and Valentine (2002b) regarding the co-productive nature of spaces and social relations, and the work of Woods \& Halfacree (2002) on multiple 'ruralities', in this paper I argue that complex rural and urban geographies are co-constructed through sexualities, sexual identities and LGBT 'equalities' (see also Browne \& <author name redacted>) and related legislation. In the UK the most significant piece of such legislation is the Equality Act $2010^{1}$, which in addition to its other functions establishes three duties for public sector organisations (including local authorities) - eliminating discrimination, advancing equality of opportunity, and fostering good relations (Crown 2010: 149:1a-c). Surprisingly little has been written on the rural/urban binary and LGBTI equalities-related legislation and policymaking (although see Richardson \& Monro 2012). Drawing on evidence from the participatory action research project 'LGBT Equalities in Hastings, Rother \& East Sussex' (detailed in the following Section 3), I show that the urban/rural dynamic remains of vital importance in understanding and researching public sector LGBT equalities. It seems significant that despite not being addressed in key LGBT equalities legislation (Crown 2010), rural and urban imaginaries continue to be used by local policymakers to frame and understand equalities implementation. However, I also highlight ways intricate discursive and material framings through which this urban/rural dynamic is complicated. I demonstrate how public sector discourses around LGBT equalities produce not binaristic but rather relational and 'slippery' urbans and rurals which can adhere or detach from particular areas; I also note the potential importance of alternative geographic imaginaries which an overreliance on the urban/rural dynamic may gloss over.

\footnotetext{
${ }^{1}$ The Equality Act 2010 was developed to unify and replace existing anti-discrimination legislation in the UK. As such the Act currently provides the UK's main legislative framework for improving equalities and tackling discrimination. It establishes nine 'Protected Characteristics', two of which ('sexual orientation' and 'gender reassignment') relate particularly to LGBT people.
} 


\section{3. 'LGBT Equalities in Hastings, Rother \& East Sussex' - A Participatory Action Research Project}

The introduction of the Equality Act 2010 marked the end of a decade of equalities legislation in the UK which had addressed discrimination and social exclusion on the basis of gender and sexual difference. Following this, through the years 2010 to 2013, a diverse group of public sector workers, academics, students, LGBT activists, community members and interested individuals were meeting as part of the LGBT Equalities in Hastings, Rother and East Sussex project, in the predominantly rural county of East Sussex in the South East region of the UK. East Sussex is situated on the coast of the south east of England in the United Kingdom, with a population of around 526,700 (ESCC 2012). Included within the project were the districts of Hastings, Rother, Wealden, Lewes and Eastbourne, as well as the city of Brighton \& Hove (see Figure 1). Brighton is popularly imagined as the 'gay capital of the UK' with a popular gay 'scene', a large number of LGBT community groups, a small LGBT press and some of the largest Pride celebrations in the UK (Browne \& Bakshi 2013). The districts of East Sussex include some of the wealthiest as well as some of the most deprived areas in the UK (ESCC 2012), with the latter falling particularly in the Hastings and Rother areas. As a whole, the population of East Sussex skews towards the older end compared to the rest of England (ibid) with the third-highest percentage of the population over 75 years of all English counties. In terms of employment, retail and health/social work sectors are strongly represented and account for almost a third of all employment (ESCC 2013a). East Sussex is less ethnically-diverse than England as a whole, with black and minority ethnic (BME)-identified people accounting for around $8 \%$ of the population (ESCC 2013b) - however this differs across the various local authorities. 


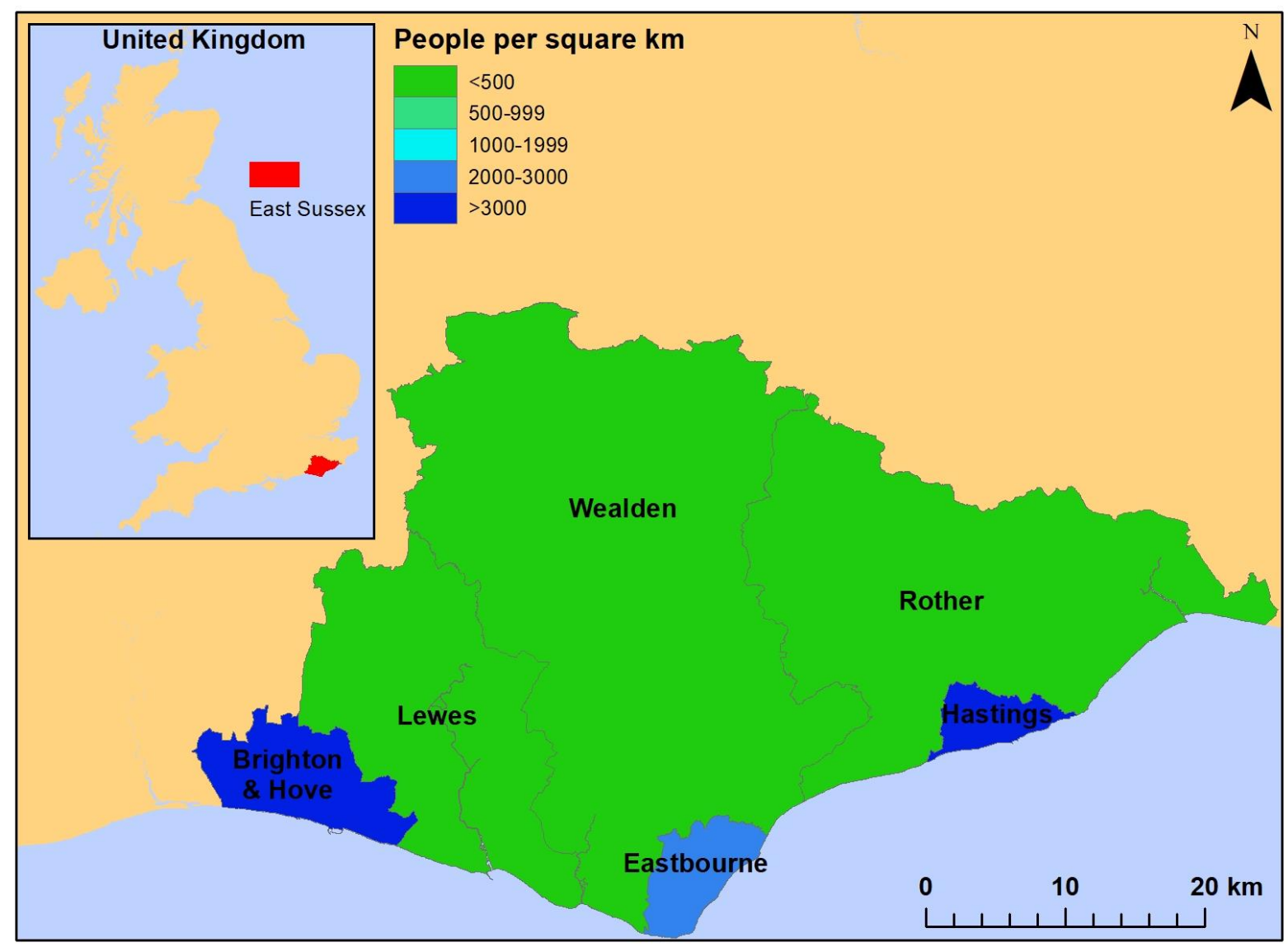

Figure 1: Population densities and local authority boundaries of East Sussex and Brighton \& Hove Source: Map created by Jay 2017; population data via Office for National Statistics (ONS 2012)

During its three years of meetings, the project forum raised and discussed issues pertinent to public sector LGBT equalities work throughout East Sussex. The LGBT Equalities In Hastings, Rother \& East Sussex project, and the twinned doctoral thesis from which this paper stems, were funded through the University of Brighton's Community/University Partnership Programme (Cupp). The specific funding stream was the 'On Our Doorsteps' initiative which aimed to make the university a better 'neighbour' to its local communities (University of Brighton 2016). As such, a Participatory Action Research (PAR) methodology was utilised in order to progress equalities for LGBT communities in the local area, and to produce empirical evidence of benefit to all partners (see Box 1). 


\section{Box 1: Partners of the LGBT Equalities in Hastings, Rother and East Sussex project}

- BourneOut (LGBT community group)

- Care for the Carers

- Crime Reduction Initiatives

- East Sussex County Council (including Adult Social Care, Children's Services, and Libraries \& Information Service departments)

- East Sussex Fire \& Rescue Service

- East Sussex Hospitals NHS Trust

- Hastings \& Rother Health \& Social Care Forum

- Hastings \& Rother Rainbow Alliance (LGBT community group)

- Hastings Borough Council

- Hastings Voluntary Action

- Her Majesty's Prison Service (HMP Lewes)

- NHS Hastings and Rother

- Rother District Council

- Sussex Partnership NHS Foundation Trust

- Sussex Police

- University of Brighton

- Wealden District Council

This diverse array of partners sought a variety of evidence types to address LGBT equality issues in public sector organisations and to establish the issues faced by local LGBT communities. Crucially, this evidence was to be of use in convincing policymakers and advocating for change at a variety of levels. A mixed-methods approach was agreed on by partners to meet these multiple aims. Therefore this PAR produced and analysed both quantitative and qualitative data resulting in two outputs - a Mapping Exercise of local LGBT-related equality policies (see <author name redacted>), and an extensive Online Questionnaire (see <author name redacted>) $)^{2}$.

A series of routed quantitative and qualitative questions forming the Mapping Exercise were developed by project partners in mid-2010. These were informed by the aims and concerns of partners; by foregoing LGBT-focused research in the Hastings area (Fairley \& Nouidjem 2004); and by the public sector equality duties of the Equality Act 2010 (Crown 2010: 149:1a-c). Questions were

\footnotetext{
${ }^{2}$ Note that while these 174 respondents' qualitative answers were used as data in my doctoral research, this sample was reduced to 128 respondents for the purposes of the Online Questionnaire Report (<author name redacted>) to meet the strict geographic remits of the Equalities Forum's various partners and ensure maximum comparability with their own research. See <author name redacted>: 12 for further details.
} 
sent via email by the author in November 2010, and organisations were asked to provide supporting evidence wherever possible. Ten local public sector organisations responded to the Mapping Exercise questions (see Box 2). Data was coded and organised by the academic researchers, and subsequently analysed by partners via email and in forum meetings. A Mapping Exercise report was produced which outlined key findings (<author name redacted>).

\section{Box 2: Mapping Exercise responding organisations}

- East Sussex Hospitals NHS Trust

- East Sussex County Council (including Adult Social Care, Children's Services and Library \& Information Service)

- Hastings Borough Council

- Rother District Council

- Wealden District Council

- NHS Hastings and Rother

- Sussex Police

- Sussex Partnership NHS Foundation Trust

- University of Brighton

- East Sussex Fire \& Rescue Service

The more extensive Online Questionnaire was also developed by project partners through forum meetings and via email. The final routed questionnaire was composed of 116 questions, themed to address LGBT demographics; health and wellbeing; safety; areas of living, working and socialising; policies and legislation; public services; and local community groups. Questionnaire sampling operated via pre-existing contact networks maintained by the academic researchers and forum members; snowball sampling through previous respondents; flyer distribution in local LGBT and 'mainstream' community spaces; and notices in local press and publications, including those of participating public services and community groups. The Online Questionnaire was implemented via the popular survey website www.surveymonkey.com. To allow those without personal computers to participate, four 'drop-in' sessions were organised at which those wanting to complete the questionnaire were able to do so with the assistance of a researcher. The questionnaire was live from November 2011 to March 2012, and was answered by 174 local LGBT people. A dedicated 
analysis group was formed from the project partners, and over four meetings these ten partners analysed both the qualitative and quantitative data. As with the Mapping Exercise analysis the main researcher coded and organised data using NVivo and SPSS analysis software, and conducted statistical analyses as advised by the group. A new Online Questionnaire Report was published with findings from this analysis (<author name redacted>).

In addition to data generated through the Mapping Exercise and the Online Questionnaire, forum meetings of the LGBT Equalities in Hasting, Rother and East Sussex project were themselves audio recorded and used as data for my own mixed-methods doctoral thesis (for a fuller account of the project see <author name redacted>) which explored the geographies of community/public sector partnership work for LGBT equalities in East Sussex. The forums aimed to provide a space for a variety of public, voluntary, community and academic groups and individuals to meet, strengthen networks, share best practice in developing LGBT equality policies, and engage in further research (see Box 3 for an example of a forum meeting agenda). In essence, these forum meetings formed the participatory hub through which the rest of the project operated. From the initial meeting in May 2010 to the last meeting of August 2012, these forum meetings were planned on a roughly bimonthly basis, with 13 forum meetings in all occurring over this period. 11 of these meetings were audio recorded, and they were hosted by the University of Brighton's campus in Hastings - partners suggested that this was felt to be a 'neutral' space in addition to being geographically central for many partners. 


\section{Box 3: Sample Forum Meeting Agenda}

Lesbian, Gay, Bi and Trans Equalities in Hastings, Rother \& East Sussex Group

24th January 2012 @ The University of Brighton in Hastings

\section{Agenda:}

1. Welcome

2. Last meeting's minutes and actions

3. 'What Have You Done For Us Lately' - mapping exercise feedback/evaluation

4. Online questionnaire - initial demographic stats

5. Online questionnaire - preparing analysis group

6. LGBT equalities issues - open discussion

7. Next meeting

Analyses of the data operated differently between the PAR analyses to produce the Mapping Exercise report and the Online Questionnaire report on the one hand, and the author's individual analysis as part of his PhD thesis on the other. PAR analyses of quantitative data centred on the author performing simple statistical tests of frequency and correlation as advised by partners. These simpler tests were used to maximise accessibility of the analysis process for partners, and the findings for the intended audience of public sector workers and local LGBT individuals. PAR analyses of the qualitative data utilised the thematic analysis methodology outlined by Braun and Clarke (2006). An initial thematic coding was undertaken by the researchers and the coded data and themes reviewed and revised by project partners.

The author's own individual analysis adopted a discourse analysis inspired by the legacy of scholarship surrounding Michel Foucault. Rather than seeking to uncover any hidden truth or subtext of the recordings, a Foucauldian discourse analysis explores the communication between the texts, one's own self, and wider societal issues of institutionalised power and subjectivity (Graham 2012:665). Parker's guidelines for Foucauldian discourse analysis were utilised for this process, particularly as involved free associative brainstorming, and the systematic itemisation of / study of interaction between objects and subjects (Parker 2004). As such my analysis here centres on reading networks of performative and discursive relationships through the text, identifying 
subjectivities and the modes of subjectification. Qualitative data from the forum meetings, the Mapping Exercise and the Online Questionnaire were imported directly into NVivo, with the transcripts organised chronologically and responses from the two questionnaires separated by individual question and listed in order of date received.

\section{LGBT Equalities Work and a Challenge to Rural/Urban Dynamics}

As noted in the previous Section 3, much of the foregoing geographic literature has engaged with sexuality (and, admittedly to a much lesser extent, gender identity) through the binary rubric of 'the urban' and 'the rural, with particular features of each seen to be of significance with regard to LGBT lives. For the rest of this paper I explore how this urban/rural dynamic could be seen to operate within the LGBT Equalities for Hastings, Rother and East Sussex project, and I demonstrate how this dynamic is complicated and challenged by the practices and discourses of public sector LGBT equalities. In this section I first highlight the relationality of the various rural and urban areas of Brighton \& Hove and East Sussex through the movements of LGBT individuals across multiple boundaries of relevance to public sector LGBT equalities work. I then showcase data from the LGBT Equalities project which serves to further complicate these urban/rural boundaries. What is rural, as Halfacree has noted, 'may be very different in different places and at different times - it is irredeemably contextual' (Halfacree 2004:303). While this might (rightly) encourage us to consider the shifting contexts of large expanses of space and time, in my research the 'different places' and 'different times' can be the different discussions in a series of meetings over a few years, or even within one meeting. Most particularly, this data demonstrates the ways in which various specific areas of the research were framed as urban or rural in different relational contexts. That is to say, for example, that the town of Hastings was framed as 'rural' in some contexts, and 'urban' in others. These relational contexts, I argue, were heavily influenced by the discourses of public sector LGBT equalities, and furthermore can lead to the elision of significant LGBT equality issues. 


\section{1 - Complicating the Rural/Urban Binary Through LGBT Boundary-Crossings}

Exploring public sector LGBT equalities work highlights the instability and relational entanglement (Massey 2004) of areas framed as 'urban' or 'rural'. Although many rural dwellers (both LGBT and non-LBGT) travel to urban areas to access services or for socialising (Gorman-Murray et al 2012; Gosnell \& Abrams 2011), the point of this section is not simply to note such flows but to explore how they link to and re/produce specific and relational rural/urban imaginaries within a context of public sector LGBT equalities work (which is not reducible to the provision of public services - see <author name redacted>).

Firstly, the provision of public sector services reveals alternative political, legislative and servicebased boundaries and divisions, brought to the fore by the distances in wider East Sussex. Forum attendees who represented public sector organisations often commented on the difficulties their organisations faced when trying to work for LGBT equalities across their different geographical remits, particularly where they overlapped with other services and across multiple geopolitical boundaries. In East Sussex, the physical distances and the differing political and legislative boundaries of various public sector organisations are vital to considerations of LGBT equalities and yet cannot be reduced to an urban/rural dynamic. One public sector representative on the equalities forum, Karen, emphasised this in a 2011 meeting, showing how public sector service provision for LGBT people in East Sussex escapes the boundaries of the urban and the rural:

Karen - 'In the havens and Lewes and Wealden area, which is the north of the county, it's less of a clear picture... The main problem is that their main populations look in three different directions for their main healthcare provider. So Brighton, Tonbridge Wells or East Sussex.' 
Karen describes a broad swathe of East Sussex here, from 'the havens' (Peacehaven and Newhaven) on the south coast, the town of Lewes to the west and the district of Wealden to the north. The areas of service provision described points to LGBT people from these areas accessing services at a distance from their area of residence, as pointed out in other literature on rural and nonmetropolitan LGBT lives (Friedman 1997; Gray 2009; Smith 1997). However, the data demonstrates that this phenomenon does not only operate with regard to service provision. Individuals increasingly move across urban and rural spaces for work, challenging easy labelling of some lives as simply 'urban' or 'rural'. Data gathered through the Online Questionnaire revealed this to indeed be the case for LGBT people in East Sussex, with less than half of respondents saying that they live in the same area as they work, volunteer or study $(42.2 \%, n$. 54). Perhaps crucially for LGBT people and LGBT communities, however, the data also reveals a great deal of travel not just for access to services, but for the purposes of socialising with other LGBT people, particularly travel to Brighton. While discussing how to address the various geographies of respondents to the Online Questionnaire during its development, forum member Edward explained how he felt such movement operated in the Hastings and Bexhill areas of East Sussex regarding other communities:

Edward - 'What is interesting is that you find people who, you know they've all their life they've been in one place, but they have interests in issues that are affecting another part of a community, and that is really common for worship and... Well we have members of a community, living in Hastings but they worship, let's say in the Muslim community in Bexhill. Not only that, but they have interests in Hastings, they don't know much of what is going on in Bexhill.' 
Edward develops an image of residents of a particular area who, while in some senses fixed in one place for 'all their life', are at the same time attached through their membership in a community of 'interests' to a different place. However, in Edward's construction this community's awareness and interests are divided unevenly across these spaces, so that while they live in Hastings and worship in Bexhill, nevertheless 'they have interests in Hastings [and] don't know much of what is going on in Bexhill.' If, as Edward suggested, we reflect on how LGBT communities themselves may operate in such geographically complex ways, we may consider how the supposedly urban LGBT communities of Brighton are in part composed of rural and 'non-urban' LGBT people, and indeed the distinct LGBT communities of Hastings, Eastbourne and so forth. The project's Online Questionnaire found that LGBT respondents living in East Sussex (but outside of Brighton) often primarily socialised in Brighton (Table 1; see also <author name redacted>: 42-46) and of those who travelled to socialise with other LGBT people they most often travelled to Brighton (see Table 2; see also <author name redacted>: 42-46).

\begin{tabular}{|l|l|l|}
\hline $\begin{array}{l}\text { Table 1: Which } \\
\text { of these areas } \\
\text { do respondents } \\
\text { mainly socialise } \\
\text { in? }\end{array}$ & \multicolumn{2}{|l|}{. } \\
\hline & Frequency & Valid \% \\
\hline Hastings & 36 & 39.1 \\
\hline Rother & 7 & 7.6 \\
\hline Wealden & 3 & 3.3 \\
\hline Eastbourne & 9 & 9.8 \\
\hline Lewes & 2 & 2.2 \\
\hline Brighton \& Hove & 27 & 29.3 \\
\hline $\begin{array}{l}\text { Not in East } \\
\text { Sussex }\end{array}$ & 4 & 4.3 \\
\hline Don't know & 1 & 1.1 \\
\hline N/A & 3 & 3.3 \\
\hline Total & 92 & 100.0 \\
\hline Missing & 36 & \\
\hline Total & 128 & \\
\hline
\end{tabular}

\begin{tabular}{|l|l|}
\hline $\begin{array}{l}\text { Table 2: In the past } \\
\text { year, have respondents } \\
\text { ever gone away from } \\
\text { where they live to } \\
\text { socialise with LGBT } \\
\text { people? (qualitative } \\
\text { responses) }\end{array}$ & Frequency \\
\hline Brighton & 24 \\
\hline London & 21 \\
\hline Hastings & 5 \\
\hline Eastbourne & 5 \\
\hline
\end{tabular}

These responses often discursively framed Brighton (and sometimes London) as the place where LGBT socialising was to happen for those in wider East Sussex: 
- Small circle of friends, none of whom are gay / bi males. Feels like nowhere to go. Heading to Brighton means having to catch last train home at 2330, meaning nights out are of limited value to enjoy night life. No local LGBT friendly venues to attend that I am aware of. (Respondent \#96)

- If I wanted a gay scene Brighton and London are on my doorstep. (Respondent \#115)

- No clubs or events where we are able to socialise in Bexhill, Brighton too far to travel. (Respondent \#128)

Per Karen's earlier comment that local LGBT people 'look in three different directions' for healthcare, we know that the same is true regarding services, and Edward's comment also points to feelings of community. The suggestion that the 'rural' of LGBT East Sussex bleeds into the 'urban' of LGBT Brighton, thwarting attempts to clearly distinguish between them. Similarly, Brighton's urbanity must also bleed into surrounding rural areas through the reverse flows of movement of LGBT bodies and communities, public sector services, and discourses of sexuality and gender identity - much of urban, 'Gay Capital' Brighton (Browne \& Bakshi 2013) may actually composed of workers and people socialising from 'rural' areas which are potentially (noted by Respondent \#96, Respondent \#128 and others) more than an hour's travel away. This multifarious evidence regarding the flows and boundary-crossing movements of LGBT people across East Sussex and Brighton \& Hove highlights the relationality of urban and rural LGBT communities.

\section{2 - Complicating the Rural/Urban Binary Through Public Sector LGBT Equalities Discourse}

While the boundary-crossing discussion of the urban and the rural appears to map rather neatly onto the areas of Brighton and wider East Sussex, in-depth analysis of the qualitative data reveals how such public sector equalities discourse exceeds such limits and is thus revealed to be considerably more complex. I now move on to detail such complexities through a relational 
geographic lens. What I am arguing here is that distinct areas of East Sussex and surrounds were framed as either urban or rural in relational to other areas. Most crucially, I demonstrate that public sector LGBT equalities discourse was central to this and that these discourses framed particular areas as both urban and rural (though not in the same context). These slippery urban or rural framings have significant implications for progressing LGBT equalities work in these areas.

To begin, the discursive production of 'rural' as well as 'urban' in the qualitative data emerged through discussions of local LGBT equalities in a relational geographic framework. The following exemplar excerpt is taken from early in a meeting of the Online Questionnaire analysis group (composed of members from and meeting in lieu of that month's LGBT Equalities Forum). Aaron quickly seizes on a geographic issue:

\author{
Aaron - 'What was the geographic spread, did we get rural Rother?' \\ $<$ brief interruption> \\ Researcher 1 - 'We've put the geographical areas into the local districts basically, it's a \\ question of do you live in Brighton and Hove, Hastings, Lewes, Rother, Wealden, Eastbourne, \\ so it's kind of the local council districts we're interested in.'
}

Aaron - 'And did we manage to get all districts or was it largely Eastbourne and Hastings?'

LGBT Equalities Forum Meeting, May 2012

The area of concern here is immediately focused on 'rural Rother'. Aaron's identification of this particular area suggests that it is considered the most important, as a 'rural' area, to gain knowledge of with regard to LGBT lives, communities and needs through the questionnaire. After the researcher has outlined the list of areas into which respondents were sorted Aaron then suggests an 
expectation of respondents hailing primarily from the Eastbourne and Hastings area. The discursive construction of this expectation through 'did we manage' seems to imply an element of failure in gathering most respondents from the Eastbourne and Hastings areas, particularly when 'rural Rother' has already been identified as the key area of concern. Indeed, the 'rural' aspect of this area can be said to be produced through a fear or expectation of lower LGBT engagement and greater LGBT problems. Aaron's framing of the 'geographic spread', therefore, suggests that knowledge of LGBT lives in Eastbourne and Hastings - the largest towns within the geographic remit of the Online Questionnaire - is considered less important than knowledge of 'rural Rother'. This is understandable as data on rural LGBT lives in the UK is indeed sparse, however the construction of equivalent data regarding Eastbourne and Hastings is somewhat more problematic. As the findings of the project's Online Questionnaire (<author name redacted>) and others (Fairley \& Nouidjem 2004) demonstrated there remain real and pressing concerns for LGBT people in all areas of East Sussex, not just those areas coded as 'rural'. Indeed as Gavin Brown has pointed out, there is in fact an acute dearth of research on LGBT lives in smaller cities and towns (Brown 2008) such as Eastbourne and Hastings.

A key distinction emerging here hinges on discursive constructions of the rural and the urban through a relational geography of LGBT equalities. LGBT lives and needs in Rother are coded as more in need of public sector attention because of their connection with rurality, through assumptions of rural areas being devoid of LGBT communities and services and therefore as most in need. By way of contrast, towns like Hastings and Eastbourne appear marked out because of their status as larger towns in East Sussex, and yet in other contexts glossed over as 'out of place'. Comments in a future meeting of the forum's analysis group seem to explain how such distinctions are constructed through the discourse of LGBT public service provision. In the following excerpt, Emily is discussing the provision of services supporting LGBT people with mental health difficulties: 
Emily - 'But maybe it would be interesting to see if some of them were rural and some of them were urban people. And maybe, I wouldn't be surprised if it pointed to people in the urban area are getting more support, perhaps than living in the sticks.'

LGBT Equalities Forum meeting, June 2012

Crucially, the data explored in these analysis group meetings specifically excluded respondents living, working and socialising primarily in the city of Brighton \& Hove, and yet the comparative rural/urban binary is still the frame through which Emily views expectations of public sector service provision. In fact, based on Emily's comments here, the analysis group moved on to agree that respondents experiences of mental health difficulties should be crosstabulated against a rural/urban category, through which both Hastings and Eastbourne (with Brighton still excluded) were to be coded as urban. James confirmed this when he followed up Emily's suggestion:

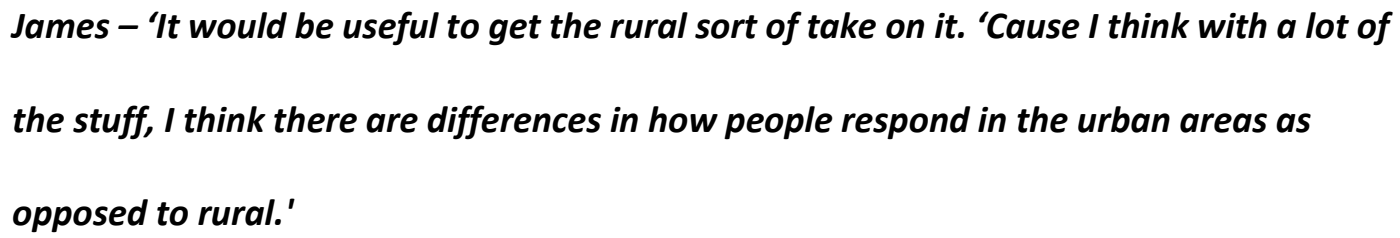

James' comments here reinforce Emily's discursive framing. Through rural/urban discourse LGBT people in certain areas (such as Hastings and Eastbourne) are framed as being less in need of public sector support than other areas, despite the fact that Hastings and Eastbourne are heavily underresearched and that their LGBT communities face considerable challenges (Fairley \& Nouidjem 2004; <author name redacted>). This clearly demonstrates that 'urban' is contextualised through a 
relational geography of public sector LGBT equalities. In the foregoing quotes from Lara, Emily and James, towns such as Hastings and Eastbourne become the urbans in contrast to which other areas of East Sussex are rural. At other times in the forum meetings the districts of East Sussex, crucially including the towns of Hastings and Eastbourne, were used by forum participants to frame Brighton as urban:

Aaron - 'A lot of people were younger and have maybe moved to Brighton or are still rooted in East Sussex, you know as you do when you are younger, you go to the big city'

LGBT Equalities Forum meeting, May 2012

Aaron draws on the common trope of mass rural to urban gay migration (Weston 1995), with Brighton as the 'big city' and East Sussex as the rural area by way of relation. In another meeting James, Karen and Julian discussed LGBT people from Hastings travelling to Brighton to socialise:

James - 'When you're here [Hastings] going to Brighton can feel like the big city. You know, bright lights big city.'

Karen - 'Ooooh, Brighton!' [laughs]

[general laughter]

James - 'I know, I know [laughs]. But it is!'

Julian - 'We're laughing, sorry James, but I think if you've lived in a proper urban city and then you come to Brighton, it can feel quite small.' 
While demonstrating that Brighton the 'gay capital' can take on the role of the 'big city' for LGBT people in Hastings (such as James) Karen and Julian's amused reactions highlight the discursive contradictions occurring through the urban imaginary here. As with Aaron Brighton is again deployed as the 'big city' in relation to an area of East Sussex - this time specifically the town of Hastings. But simultaneously Brighton is framed as 'quite small' in relation to 'a proper urban city' (which Brighton, in Julian's estimation, is evidently not).

We can further explore the emerging complexity of these relational geographies of LGBT equalities through Lara's comments from a subsequent meeting. She explained that Eastbourne was often seen as 'out of place' in East Sussex or as a poorly-acknowledged liminal space, which she describes as a 'Twilight Zone':

Lara - 'Eastbourne's a bit like the Twilight Zone sometimes, I think.'

James: 'More like the twilight years zone!'

[general laughter]

Lara - 'But it's bigger than Brighton, Eastbourne's bigger than Brighton, but Brighton's a city.

Maybe it's Brighton that's out of place between Hastings and Eastbourne.'

LGBT Equalities Forum Meeting, July 2011

Here Lara deploys a relational geographic framework to understand Eastbourne as well as Brighton. Reacting against the framing of Eastbourne as 'out of place', Lara turns this back on Brighton to suggest that its city status may mask its own 'out of place'-ness as a small city. Lara's assertion that Eastbourne is larger than Brighton further complicates the issue. The area of the city of Brighton \& Hove is around double that of Eastbourne ${ }^{3}$. However Lara specifies 'Brighton' which, while often

${ }^{3} 8279$ hectares to 4416 hectares, respectively (ONS 2017). 
used synonymously with the conjoined administrative district of the city of Brighton \& Hove, has its own unique geographic imaginary regarding LGBT equalities (see Section 5) which Lara draws on. Separated from Hove, Lara may indeed envisage Brighton as comparable in size to Eastbourne, inviting us to critically reconsider how and why towns like Eastbourne are seen as 'Twilight Zone[s]' and produced as 'out of place' in wider conceptualisations of the region.

Public sector discourse surrounding the geographies of LGBT lives and needs therefore highlights the complexity of urban/rural distinctions. Far from being fixed or attached only to particular areas, the data points to multiple 'urbans' incorporating a variety of different geographies, imaginaries and population centres, and additionally can attach or detach to/from different areas in different contexts, hence Hastings in these examples being variously coded as both rural and urban. The complexity here emerges through the fluidity and flexibility of rural/urban discourse, and the ability of the urban and the rural to adhere to the same area in different contexts. In some respects the ability of areas such as Hastings to be both urban and rural is reminiscent of the work of Andrew Gorman-Murray on the hybrid gay and lesbian geographies of Australia, with 'rural' Daylesford constructed through a melding of sexualised urban and rural imaginaries and materialities (in the form of transport links, services etc.) (Gorman-Murray et al 2012). However Gorman-Murray's data clearly speaks to simultaneous urbanity and rurality in Daylesford. My data regarding towns such as Hastings and Eastbourne, exemplified in the above exchange between James and Emily in the June 2012 meeting, is more suggestive of urbanity/rurality as distinct but mobile and unfixed, emerging in relation to and overlapping with other local geographies. In this way such areas are produced as urban, rural or (as outlined in the following Section 5) an alternative geographic imaginary depending on the political, material and/or discursive context - and in the case of my research, LGBT equalities form a particularly strong context for the production of such spaces.

The effect of these mobile geographies is such that areas like Hastings are constructed as less in need than 'more rural' areas of public sector services and support for LGBT people, with the through 
the assumption that such services and support already exist in the 'more urban' areas. Thus LGBT needs in Hastings are rendered less visible, occupying a shaky middle-ground between a 'more urban' Brighton and a 'more rural' East Sussex. When compared to Brighton, the urban/rural dynamic operates to construct urban Brighton as the place where LGBT people are, having migrated from rural East Sussex. When compared to 'rural Rother', the dynamic operates to construct LGBT Hastings as better known about and less in need than its rural neighbours. Following the extensive literature on LGBT rural imaginaries (Bell \& Valentine 1995a; D’Augelli 2006; Kramer 1995; Lindhorst 1997; Smith 1997) these rural needs themselves appear to stem in part from sexualised and gendered imaginaries of the rural as oppressive and intolerant (see also <author name redacted>; <author name redacted>). Areas such as Hastings and Eastbourne are by no means areas which are covered by existing research, and yet the interplay of geographic and public sector LGBT equalities discourses showcased in this section works to gloss over them in favour of 'rural' areas. Such discourse distinguishes areas beyond the geopolitical limits of the city, framing some nonmetropolitan areas (which might include small cities, towns and suburban areas as well as 'rural' areas) as more in need of attention than others. This may result in an overestimation of the knowledge we have of areas like Hastings and Eastbourne, and an underestimation of the issues LGBT people and communities in these areas face. Uncritical use of rural/urban discourse may in fact contribute to the neglect, both by the academy and the public sector, of such areas, which do not fit neatly into imaginaries of the urban or the rural - Lara's 'Twilight Zone'. Those areas such as Hastings and Eastbourne, which appear able to slip easily across urban and rural and yet not sit comfortably in either, may therefore be neglected when we operate within a deceptively simple urban/rural framework, which can simultaneously incorporate all areas and yet render invisible those which fall too easily within the nebulous overlap of the two. Without denying the continued discursive and political force of the urban and the rural, and their importance as discursive tools for understanding and organising LGBT lives and associated public sector equalities work, research from the LGBT Equalities in Hastings, Rother and East Sussex project points to the fluidity and slipperiness 
of such categories, and suggests how this very slipperiness may impact on LGBT lives in particular areas, especially when such areas do not easily fit into either category.

\section{The Gay Capital and the Small Town - alternative geographic imaginaries}

If the data generated through the LGBT Equalities in Hastings, Rother and East Sussex project makes us question easy urban/rural frameworks when it comes to public sector LGBT equalities, it should also encourage us consider to alternative geographic imaginaries which may offer productive new ways of engaging with LGBT equalities work. Gavin Brown has called for more research on 'ordinary cities' as a challenge to the metrocentrism in many geographic studies of LGBT lives and communities (Brown 2008), and there has been some engagement with alternative geographic imaginaries relating to LGBT lives. Yet this still appears to concentrate scholars' attention on cities qua cities, albeit a wider array of them. In this section I take up this challenge in a broader sense by suggesting other spaces and alternative geographic imaginaries which emerge through the data as also involved in the construction of LGBT lives and equalities. These are the framing of the city of Brighton \& Hove as the 'gay capital' of the UK; and the discussion of Hastings and Eastbourne (and areas of them) as 'small towns'. In these two respective sections I note that a relational analysis incorporating geographies beyond the urban/rural may help address the erasure of those places which do not fit comfortably in either urban or rural.

\section{1 - Not Just a City But The 'Gay Capital'}

The city of Brighton \& Hove is the closest city to these areas of wider East Sussex such as Hastings, Rother and Eastbourne, and questionnaire respondents and forum participants regularly referenced it with regard to issues of LGBT equality. This data, as with that regarding rural East Sussex, taps into and yet complicates assumptions and imaginaries of what the urban means to LGBT lives and communities. Familiar and well-established discourses of the urban as a place of safety, social space 
and access to LGBT-friendly public services for LGBT people (see Weston 1995; Aldrich 2004;

Hanhardt 2013) did emerge. These were entwined with discourses of the more LGBT-oppressive rural (Kramer 1995; Gray 2009)4. However Brighton emerges as a more than just another city instead, the data reveals it to be a complicated imagined space in a variety of relationships with surrounding rural and non-metropolitan East Sussex. Though respondents and forum participants alike often constructed rural versus urban comparisons and contrasts (through reference to local East Sussex geographies), the discourse used suggests that these relationships are not only a matter of binary comparison, but relating to specific imaginaries of Brighton as the 'gay capital' of the UK. For example, respondents talked about 'obviously' or 'only' feeling safe in Brighton:

- 'Obviously, I have no problem being openly gay if I'm in Brighton. But, I would err on the right side of caution elsewhere in East Sussex.' (\#108)

- 'Only in Brighton do I really relax and feel as though I have rights and that I'd be OK if something did kick-off.' (\#154)

Respondent \#154 appears to strongly associate the expectation of safety with Brighton, where is the 'only' place they feel safe. Such responses cannot be assumed to refer to Brighton only in its capacity as a city or an urban environment. While there is a dearth of academic writing about Brighton, Kath Browne, along with other authors, has written of its popular status of the 'gay capital' of the UK (Browne \& Bakshi 2013; Browne \& <author name redacted>), with ‘a long history of sexual transgressions and [which] prides itself on 'leading the way' in terms of LGBT equalities agendas' (Browne \& Bakshi 2013:16). It is this imaginary - the 'gay capital' - which seems to emerge from my

\footnotetext{
${ }^{4}$ See <author name redacted> and <author name redacted>; however it is worth noting that this tolerant urban / oppressive rural was challenged through, for example, the ranking of local public services as generally 'LGBT-friendly' and the identification of particular LGBT 'scenes' and groups in the area.
} 
data, and demands attention beyond the conflation of Brighton with the urban. LGBT respondents to the Online Questionnaire framed Brighton as exceptional and separate from other spaces through discourses which cannot be reduced to urbanity - respondent \#154 does not say 'only in cities' or 'only in Brighton or London', for example. Brighton is not simply a space of safety from sudden violence as implied by the phrase 'kick-off', but it is also the 'only' place respondent \#154 feels that they 'have rights'. Therefore while its urbanity remains an important factor (as indicated through the repetition of broader imaginaries of urban LGBT safety), Brighton is not felt to be safe simply because it is urban or because it is a city - instead, the unique geographic and cultural specificity of Brighton, the 'gay capital', contributes to feelings of a space where LGBT people will 'obviously' be safe and, simultaneously, such feelings of LGBT safety work to construct this imaginary of Brighton.

The relational nature of such imaginaries may contribute to a vicious circle, whereby particular assumptions of what LGBT space looks like (here a combination of a metronormative 'scene' and the imagined ubiquity of LGBT groups in the 'gay capital') work to further marginalise LGBT spaces beyond the city and particularly the urban metropolis, rendering them less visible because urban LGBT space (perceived as bars, clubs, community centres etc.) comes to be seen as the only form LGBT space (including rural LGBT space) can take. This occurred during one of the forum meetings:

Emily - 'I'd be willing to bet that the gay, the LGBT students, they're not going out here [in Hastings].'

Researcher 1 - 'Nah. Well, no, there's that night at [local pub]. And I mean they are going out. But yeah, I see a lot of talk on Facebook and stuff, lots of students travelling to Brighton. Complaining about not being in Brighton.'

Tricia - 'Not just students. I think most of the youngsters, HRRA is not a group for older LGBT people, it's a group for LGBT people... But the youngsters want to go for a big night out, so it's London or Brighton. Let's say the council wanted to support LGBT youngsters, is it about a 
youth group in this area, or is it more about linking up with Brighton? Because if they're going there for everything...'

LGBT Equalities Forum meeting, June 2012

When I came to analyse this meeting I was interested in my own gut reaction as Researcher 1 - 'Nah' - to Emily's suggestion that LGBT students were 'not going out' in Hastings. The rest of the discussion, and my own personal experiences while undertaking the research and socialising in Hastings, indicate that LGBT students and young people do indeed socialise in LGBT space in the area. However Emily, myself, and Tricia from the Hastings and Rother Rainbow Alliance (HRRA) continued to elide such spaces in Hastings and emphasise Brighton as their location. Respondents to the Online Questionnaire suggested similar ideas, with one bluntly stating:

- 'Hastings is just a small town in the rural south of England, I would be surprised to find gay bars here!!' (\#21)

Other data from the Online Questionnaire, however, demonstrates a variety of different spaces for LGBT socialising in East Sussex. Respondents primarily living, working and socialising outside of Brighton were asked what LGBT spaces they went to:

\begin{tabular}{|l|l|}
\hline $\begin{array}{l}\text { Table 3: Where do you go to } \\
\text { socialise? }\end{array}$ & Frequency \\
\hline Bars, pubs or clubs & 24 \\
\hline Houses of family/friends & 14 \\
\hline Community groups or centres & 10 \\
\hline Theatre or cinema & 8 \\
\hline Cafes & 5 \\
\hline
\end{tabular}

While 'bars, pubs or clubs' are still heavily represented here, metronormative understandings of LGBT space which present bars and 'gay villages' as the most important sites of LGBT community and socialising not only elide the other spatialised forms of LGBT community taking place beyond the 
urban, but may in fact contribute to their relative invisibility. Rather than simply offering an important site of LGBT community and socialising in East Sussex, then, imaginaries of the gay capital may actually be implicated in the dearth of such socialising across East Sussex's more rural areas because fewer people can become aware that it exists albeit in different forms such as LGBT socialising in private houses or events etc. (<author name redacted>: 43-44; see Gray 2009). In the above discussion from the June 2012 meeting, Tricia raises a crucial point regarding the distribution of public sector resources and capacity for young LGBT people. Should (more) resources be put into Brighton's LGBT communities to support those young people travelling to participate in them? If that were to occur, it could contribute to the perception that Brighton's status as the 'gay capital' leads to the drawing of material resources away from LGBT groups and initiatives in surrounding East Sussex:

Julian - 'You're close to a big conurbation [Brighton] that gets all the money, all the effort goes. And close by, this little LGBT community [Hastings and Rother] gets nothing' questions here. Though Massey frames such geographies primarily through a global/local lens, by deploying her critique here we can see public sector LGBT equalities work in East Sussex and Brighton \& Hove enmeshed in a relational geography of responsibility. Here urban/rural may be a more informative referent than global/local. On the one hand resources for LGBT youth might be best allocated to Brighton 'if they're going there for everything' (Tricia). But on the other hand this contributes to the 'little LGBT community [that] gets nothing' (Julian). As Massey argues, relationality establishes 'an important shift which renders deeply problematical any easy summoning 
of 'community' either as pre-existing or as a simple aim' (Massey 2004:6), whether it be the LGBT community of Brighton or elsewhere in East Sussex. Julian uses a relational lens to implicate the 'gay capital' of Brighton in the dearth of LGBT funding in nearby areas. Though as Dom pointed out in a later meeting, even this isn't as simple as it first seems:

\section{Dom - 'Inevitably there's a perception [in hospitals outside Brighton] that we don't have any of 'those people' here because they're all in Brighton, and then in Brighton there's that sort of "Well it's Brighton so there can't be any of those sorts of issues".'}

LGBT Equalities Forum Meeting, January 2012

Per these contrasting comments from Julian and Dom, the imaginary of the 'gay capital' can go both ways, discursively configuring public sector LGBT work as variously complete, saturated and/or unnecessary (in Brighton); or as absent, in need of resources or unnecessary (in rural and nonmetropolitan East Sussex).

Attending to relationally produced geographies not just of cities but of a city as the 'gay capital' thus offers a useful alternative way for geographers to engage with the development and implementation of public sector LGBT equalities, beyond an urban/rural framework. New geographies of responsibility (Massey 2004) emerge here, which those of us who wish to progress positive social change for LGBT people in rural areas must attend to. But evidently a singular focus on the 'gay capital' comes with its own issues. The data suggests a potential double bind for those places caught in its relational construction, where the gay capital can be 'fine' and not need support in developing LGBT equalities; and its relational Other can be 'LGBT free' and therefore also not in need of support in developing LGBT equalities. 


\section{2 - LGBT 'Small Town Life'}

In addition to the 'gay capital', both Online Questionnaire respondents and forum participants used the figure of the 'small town' to explain their experiences. Some scholars have described similar geographic areas and labelled them as 'small towns' in their research (e.g. Whittier 1997), but these areas are often folded into ruralities rather than explored in their own terms. The 'small town' was explicitly used by questionnaire respondents to discuss particular experiences as LGBT people. As well as respondent \#21 in the previous Section 5.1, who described Hastings as 'just a small town in the rural South of England', other respondents framed their understanding of LGBT equalities in East Sussex around this imaginary:

- Most of my friends and colleagues are in London, where I lived for fifty eight years, or elsewhere. I've found it harder to integrate into small town life, especially gay life. (Respondent \#99)

- In my home, on the street, only in St Leonards, it's just the small town mentality, and they go out of their way to discover anything slightly different about other people. When anywhere else, London, Eastbourne, Brighton this does not happen. (Respondent \#43)

- More LGBT venues / services in the small towns. (Respondent \#54)

One Hastings-based respondent (\#99) deployed a small town imaginary when asked how easy it was to live in their area as an LGBT person. Note that this respondent does not quite describe Hastings itself as a 'small town', but rather refers to 'small town life'. This is not a description of the area itself but a particular imaginary, which the respondent compares to life in the nearby metropolis of London. Another respondent (\#43) reflected on their feelings of safety in their immediate 
surroundings of the St Leonards area of Hastings. Here the St Leonards area, formerly a small town now merged into an area of Hastings, is separated from the rest of Hastings. Such experiences happen 'only in St Leonards' (emphasis mine). St Leonards is also separated from nearby cities (London and Brighton) as well as Eastbourne, suggesting that it's the 'small town' that is operating as the key geographic distinction here. Coupled with the identification of a distinct 'small town mentality', this suggests a particular geographic imaginary which cannot be reduced to the rural. Interestingly, while Respondent 43 uses the figure of the small town to compare Hastings to Eastbourne, Respondent 54 (who lives, works AND socialises primarily in Eastbourne), when asked what would make their own life better, seems to include Eastbourne within the category of 'small towns'. This is of particular interest since respondent \#43 (above) has already linked Eastbourne with larger cities ('anywhere else, London, Eastbourne, Brighton this does not happen') through comparison with 'small town' St Leonards. Taken together, these responses suggest that the imagined 'small town' is no more a fixed category than the urban or the rural - as with other geographic imaginaries the 'small town' operates relationally and in part through reference to LGBT equalities. As with the foregoing comments with regard to Hastings, the specificity of this comment suggests that Eastbourne here cannot be simply folded into the rural or the urban, but is here constructed through an alternative and complex 'small town' geographic framework.

Areas such as Hastings occupy a particularly slippery discursive nexus, coded variously as urban and rural in specific ways and with specific effects. These areas are consequently elided from academic, public sector and indeed popular awareness of LGBT lives and communities. That questionnaire respondents \#54 and \#99 (above) did not describe their experiences in terms of rurality despite comparisons with urban areas hints at limits to how these urban and rural slippages in areas such as Hastings can operate - Hastings cannot always fit within an urban/rural dynamic, and alternative geographic imaginaries, such as 'small town life', are consequently drawn upon. Consequently, I argue that Hastings is perceived through a variety of different geographic imaginaries - including but not limited to the urban, the rural, the 'gay capital' and the 'small town' - which are themselves 
partially constructed in terms of LGBT equalities and which are discursively deployed with particular political and material effects. The data shows how Hastings can be urban; it can be rural; it can be neither; it can be a small town; and it can likely be a number of other imagined spaces as well. Greater consideration of alternative geographies such as the town or the small town, beyond urban/rural binaries, may offer new conceptualisations of geographies, sexualities and gender identities aside from tackling metronormativity by looking at rural areas. This is not to reject analyses centred around the urban and the rural, but to challenge the ways in which they may work to make those areas which slip across the two less visible.

\section{Conclusion}

This paper has explored how the urban and the rural work to construct, and in turn are constructed by, discourses of sexualities and gender identities, particularly within public sector work for LGBT equalities, and with implications for relational understandings of rural/urban geographic imaginaries more widely as well as for research, policymaking and activism for LGBT people in rural areas. Along with other geographers of sexualities I challenge imaginaries of the rural as unsafe, intolerant, isolating and void of LGBT lives or communities as well as imaginaries of the urban as safe, welcoming and the natural space of LGBT existence (Browne 2011; Comerford et al 2004;GormanMurray et al 2012; Gray 2009; Kazyak 2011; Kennedy 2010; Kirkey and Forsyth 2001; Skeggs et al 2004; Whittier 2012). More crucially, I have shown how the data gathered through the LGBT Equalities for Hastings, Rother and East Sussex project complicates easy binary definitions of urban and rural, through noting relational discursive slippages and the relatively neglected importance of specific geographic imaginaries such as the 'gay capital' and the 'small town'. Imaginaries of these rural and non-urban areas are constructed relationally through, and in turn work to construct, sexual and gendered imaginaries of LGBT lives and public sector LGBT equalities, and through an oppositional urban/rural dynamic. The work of LGBT Equalities for Hastings, Rother and East Sussex 
demonstrates how the urban and the rural are not fixed, but instead bleed into one another through the discourses of LGBT equalities work, and through embodied movement, community identifications and public sector service provision. My research takes up the challenge of geographers of sexualities like Larry Knopp (2007) as well as developing relational geographic scholarship by Massey (2005), Halfacree (2006) and Heley and Jones (2012) by exploring the messy and slippery effects of such geographies. Public sector LGBT equalities work works to produce relational urban and rural imaginaries, flowing in complicated ways with both 'urban' and 'rural' able to adhere to the same area in different discursive contexts. I argue that these slippery relational imaginaries of the urban and the rural can work to elide those areas which do not fit comfortably into 'either' urban or rural (such as Hastings) from research and broader geographic considerations of LGBT lives. Attending carefully to the multiplicity of relational geographic framings of such areas can help tackle consequent issues for public sector LGBT equalities work.

To conclude, I suggest more attention be paid to alternative geographic imaginaries such as the 'small town', not as an improvement on urban/rural dynamics which, as my research demonstrates, remain vital and important despite some suggestions of their growing irrelevance (Champion and Hugo 2004; Halfacree 1993; Lacour and Puissant 2007; Marsden et al. 1993; Mayerfield Bell et al 2010; Woods 2012). Instead, I posit such alternatives as pathways to critically engage with a wider variety of spaces, arguing that they may function where urban and rural discourses break down and render these spaces less visible. While Champion and Hugo have suggested that 'There is no longer any clear dividing line between town and countryside for individual settlements or their inhabitants' (Champion and Hugo 2004:3), my research instead suggests that there are in fact many such lines, and that they are constantly being drawn and redrawn through discourses and practices of public sector LGBT equalities work. This points to the importance of greater attention paid to such distinctions, including their messy and fluid complexities. I envisage vital future research based in the 'ordinary' small cities (Brown 2008), large towns and areas which do not fit comfortably into rural or urban, such as those explored this paper. Exploring alternative geographic imaginaries for 
LGBT people such as the 'small town' (as well as simply engaging in more research on LGBT lives in more rural areas, in areas beyond the urban metropolis, and particularly in those areas such as Hastings which don't fit comfortably within an rural/urban dynamic) may be able to produce important new insights rendered invisible by the prevailing urban/rural dynamic and also help to understand the needs of relatively neglected LGBT lives and communities. Such work would simultaneously offer an ongoing and robust challenge to metronormative impulses within geographies of sexualities, while also highlighting the unique contributions which rural geographers can bring to the study of LGBT equalities.

\section{Acknowledgements}

The author would like to thank the many participants of the LGBT Equalities in Hastings, Rother \& East Sussex project for their expertise and dedication; Prof Kath Browne, Dr Paul Gilchrist and Dr Jason Lim for their thoughtful comments on earlier drafts of this paper; and Will Jay for creating a new map of East Sussex and Brighton \& Hove.

\section{$\underline{\text { References }}$}

Abelson, M.J. (2016). "'You aren't from around here”: race, masculinity, and rural transgender men', Gender, Place \& Culture 23(11): 1535-1546.

Aldrich, R. (2004). Homosexuality and the City: an historical overview, Urban Studies 41 (9): 17191737.

Amin, A. (2004). 'Regions Unbound: towards a new politics of place', Geografiska Annaler: Series B 86(1): 33-44.

Anderson, R. K.; Kindle, P. A.; Ashley, D.; Nowak, J. A.; Callaghan, T. A.; \& Arkfeld, R. (2015). Rural Perspectives on Same-Sex Marriage, Journal of Gay and Lesbian Social Services 27 (2): 201-215.

Annes, A., \& Redlin, M. (2012). Coming Out and Coming Back: rural gay migration and the city, Journal of Rural Studies 28: 56-68.

Anlin, S. (1989). Out But Not Down: housing needs of lesbians. London: Homeless Action. 
Bech, H. (1997). When Men Meet: Homosexuality and Modernity. Chicago: University of Chicago Press.

Bell, D. \& Valentine, G. (1995a) Queer Country: Rural Lesbian and Gay Lives, Journal of Rural Studies 11 (2): 113-123.

Bell, D. \& Valentine, G. (1995b). Introduction: Orientations, in D. Bell \& G. Valentine (eds.) Mapping Desire. London: Routledge.

Bell, D. (2000). Farm Boys and Wild Men: rurality, masculinity and homosexuality, Rural Sociology 65 (4): 547-561.

Bell, D. (2006). Variations on the Rural Idyll, in P. Cloke, T. Marsden \& P. H. Mooney (eds.) Handbook of Rural Studies. London: Sage.

Bowen. A. (2005). Internet Sexuality Research with Rural Men Who Have Sex With Men: can we recruit and retain them?, The Journal of Sex Research 42 (4): 317-323.

Braun,V., \& Clarke,V. (2006). Using thematic analysis in psychology, Qualitative Research in Psychology 3 (2): 77-101.

Brown, G. (2008). Urban (Homo)Sexualities: Ordinary Cities and Ordinary Sexualities, Geography Compass 2 (4): 1215-1231.

Brown, G. (2009). Thinking Beyond Homonormativity - performative explorations of diverse gay economies, Environment \& Planning A 41: 1496-510.

Browne, K. (2011). Beyond Rural Idylls: imperfect lesbian utopias at Michigan Womyn's music festival, Journal of Rural Studies 27: 13-23.

Browne, K. and Bakshi, L. (2013). Ordinary in Brighton?: LGBT, Activisms and the City. Aldershot: Ashgate.

Bryant, L. \& Pini, B. (2011). Gender and Rurality. Ox: Routledge.

Champion, A. G. \& Hugo, G. (2004). Introduction: Moving Beyond the Rural/Urban Dichotomy, in A. G. Champion \& G. Hugo (eds.) New Forms of Urbanisation: beyond the urban-rural dichotomy. Aldershot: Ashgate.

Cloke, P. (1994) (En)culturing Political Economy: a life in the day of a 'rural geographer, in P. Cole, M. Doel, D. Matless, M. Phillips \& N. Thrift (eds.) Writing the Rural: five cultural geographies. London: Paul Chapman.

Cloke, P. (2003). Country Visions. London: Pearson Education.

Cloke, P. (2006a) Rurality and Otherness, in P. Cloke, T. Marsden \& P. H. Mooney (eds) Handbook of Rural Studies. London: Sage.

Cloke, P. (2006b). Conceptualising Rurality, in P. Cloke, T. Marsden \& P. H. Mooney (eds.) Handbook of Rural Studies. London: Sage.

Cody, J. \& Welch, P. (1997). Rural Gay Men in Northern New England: life experiences and coping styles, Journal of Homosexuality 33 (1): 51-67. 
Comerford, S. A., Henson-Stroud, M. M., Sionainn, C. \& Wheeler, E. (2004). Crone Songs: voices of lesbian elders on aging in a rural environment, Affilia 19: 418-436.

Crown (2010). Equality Act 2010. London: The Stationary Office.

D'Augelli, A. R. (2006). Coming Out, Visibility, and Creating Change: Empowering Lesbian, Gay, and Bisexual People in a Rural University Community, American Journal of Community Psychology 37: 203-210.

Doderer, Y. (2011). LGBTQs in the City, Queering Urban Space, International Journal of Urban and Regional Research 35 (2): 431-436.

Doel, M. A. (1999). Poststructuralist Geographies: the diabolical art of spatial science. Maryland: Rowman \& Littlefield.

DuPuis, E. M. (2006). Landscapes of Desires?, in P. Cloke, T. Marsden \& P. H. Mooney (eds.) Handbook of Rural Studies. London: Sage.

East Sussex County Council. (2012). 2011 Census First Release, East Sussex In Figures. http://www.eastsussexinfigures.org.uk/webview/streamServerFile.jsp?file=/nesstar/temp/EGMS201 21206132232208/2011\%20Census\%20First\%20release.pdf\&server=http://www.eastsussexinfigures. org.uk:80, accessed 19/1/14.

East Sussex County Council. (2013a). 2011 Census Workforce Characteristics, East Sussex In Figures. http://www.eastsussexinfigures.org.uk/webview/streamServerFile.jsp?file=/nesstar/temp/EGMS201 30521142522549/2011\%20Census\%20Workforce\%20characteristics.pdf\&server=http://www.eastsu ssexinfigures.org.uk:80, accessed 2/2/14.

East Sussex County Council. (2013b). 2011 Census Equalities, East Sussex In Figures. http://www.eastsussexinfigures.org.uk/webview/streamServerFile.jsp?file=/nesstar/temp/EGMS201 30521142522549/2011\%20Census\%20Workforce\%20characteristics.pdf\&server=http://www.eastsu ssexinfigures.org.uk:80, accessed 19/1/14.

Fairley, A. \& Nouidjem, N. (2004). Go Hastings!: Report of findings from research into the gay, lesbian, bisexual and transgendered community in Hastings \& St Leonards, East Sussex. Hastings: Hastings \& Rother Rainbow Alliance.

Fellows, W. (1996). Farm Boys: Lives of Gay Men from the Rural Midwest. Wisconsin: Uni of Wisconsin Press.

Fenge, L. \& Jones,K. (2012). Gay and Pleasant Land? Exploring Sexuality, Ageing and Rurality in a Multi-Method, Performative Project, British Journal of Social Work 42: 300-317.

Friedman, L.J. (1997). Rural Lesbian Mothers and Their Families, in J.D. Smith \& R.J. Mancoske (eds.) Rural Gays and Lesbians - Building on the Strengths of Communities 73-82. New York: Haworth Press.

Gallent, N., Juntti, M., Kidd, S. \& Shaw, D. (2008). Introduction to Rural Planning. Ox: Routledge.

Gorman-Murray, A. (2007). Rethinking Queer Migration Through the Body, Social and Cultural Geography 8 (1).

Gorman-Murray, A. (2009). What's The Meaning of ChillOut? Rural/urban difference and the cultural significance of Australia's largest rural GLBTQ festival, Rural Society 19 (1): 71-86. 
Gorman-Murray, A., Waitt, G. \& Gibson, C. (2012). Chilling Out in 'Cosmopolitan Country': Urban/rural hybridity and the construction of Daylesford as a 'lesbian and gay rural idyll', Journal of Rural Studies 28: 69-79.

Gosnell, H., \& Abrams, J. (2011). Amenity Migration: diverse conceptualizations of drivers, socioeconomic dimensions, and emerging challenges, GeoJournal 76(4): 303-322.

Graham, L. J. (2012). The Product of Text and 'Other' Statements: Discourse Analysis and the Critical Use of Foucault, Educational Philosophy and Theory 43(6): 663-674.

Gray, M. L. (2009) Out in the Country: youth, media, and queer visibility in rural America. London: NYU Press.

Gregson, N. \& Rose, G. (2000). 'Taking Butler Elsewhere: performativities, spatialities and subjectivites', Environment and Planning D: Society and Space 18: 433-452.

Haag, A. M. \& Chang, F. K. (1997). The Impact of Electronic Networking on the Lesbian and Gay Community, in J.D. Smith \& R.J. Mancoske (eds.) Rural Gays and Lesbians - Building on the Strengths of Communities 83-94. New York: Haworth Press.

Halberstam, J. (2005). In a Queer Time and Place: transgender bodies, subcultural lives. NY: New York University Press.

Halfacree, K. (2004). Rethinking Rurality, in A. G. Champion \& G. Hugo (eds.) New Forms of Urbanisation: beyond the urban-rural dichotomy. Aldershot: Ashgate.

Halfacree, K. (2006). Rural Space: constructing a three-fold architecture, in P. Cloke, T. Marsden \& P. H. Mooney (eds.) Handbook of Rural Studies. London: Sage.

Hanhardt, C. B. (2013). Safe Space: gay neighborhood history and the politics of violence. Durham: Duke University Press.

Heley, J. \& Jones, L. (2012). 'Relational Rurals: some thoughts on relating things and theory in rural studies', Journal of Rural Studies 28 (3): 208-217.

Hemingway, J. (2006). 'Sexual Learning and the Seaside: relocating the dirty weekend and teenage girls' sexuality', Sex Education: Sexuality, Society and Learning 6 (4): 429-443.

Herring, S. (2007). 'Out of the Closets, Into the Woods: RFD, Country Women, and the postStonewall emergence of queer anti-urbanism', American Quarterly 59 (20): 341-372.

Hoggart, K. (1990). Let’s Do Away With Rural, Journal of Rural Studies 6 (3): 245-257.

Holloway, L. \& Kneafsey, M. (2004). Geographies of Rural Cultures and Societies: introduction, in L. Holloway \& M. Kneafsey (eds.) Geographies of Rural Cultures and Societies. Aldershot: Ashgate.

Howard, J. (1999). Men Like That: a southern queer history. Chicago: University of Chicago Press.

HRRA (2015). Hastings and Rother Rainbow Alliance - Supporting the Lesbian, Gay, Bisexual and Trans (LGBT) Communities of Hastings and Rother, http://www.hrra.org.uk/, accessed 2/9/15.

Jay, W. (2017). Map demonstrating population densities and local authority boundaries of East Sussex and Brighton \& Hove. University of Brighton, unpublished. 
Johnston, L. and Longhurst, R. (2009). Space, Place, and Sex: Geographies of Sexualities. London: Rowman \& Littlefield Publishers.

Jones, M. (2009). 'Phase Space: geography, relational thinking, and beyond', Progress in Human Geography 33 (4): 487-506.

Kazyak, E. (2011). Disrupting Cultural Selves: Constructing Gay and Lesbian Identities in Rural Locales, Qualitative Sociology 34 (4): 561-581.

Kennedy, M. (2010). Rural Men, Sexual Identity and Community, Journal of Homosexuality 57 (1): 1051-1091.

Kirkey, K. \& Forsyth, A. (2001). Men in the Valley: gay male life on the suburban rural fringe, Journal of Rural Studies 17: 421-441.

Knopp, L. (1998). Sexuality and Urban Space - gay male identity politics in the United States, the United Kingdom and Australia, in R. Fincher \& J. M. Jacobs (eds.) Cities of Difference. NY: Guilford Press.

Kramer, J. L. (1995) Bachelor Farmers and Spinsters: gay and lesbian identities and communities in rural North Dakota, in D. Bell \& G. Valentine (eds.) Mapping Desire: geographies of sexualities. London: Routledge.

Kuhar, R. \& Švab, A. (2013). The Only Gay in the Village? Everyday Life of Gays and Lesbians in Rural Slovenia, Journal of Homosexuality http://www.tandfonline.com/doi/abs/10.1080/00918369.2014.872492, accessed 25/2/2014.

Lacour, C., \& Puissant, S. (2007). Re-urbanity: urbanising the rural and ruralising the urban. Environment and Planning A, 39 (3): 728-747.

Lapping, M. B. (2006). Rural Policy and Planning, in P. Cloke, T. Marsden \& P. H. Mooney (eds.) Handbook of Rural Studies. London: Sage.

Lindhorst,T. (1997). Lesbians and Gay Men in the Country: Practice Implications for Rural Social Workers, in J.D. Smith \& R.J. Mancoske (eds.) Rural Gays and Lesbians - Building on the Strengths of Communities 1-11. New York: Haworth Press.

Little, J. (2003). Riding the Rural Love Train: heterosexuality and the rural community, Sociologia Ruralis 43 (4): 401-417.

Marsden, T., J. Murdoch, P. Lowe, R. Munton, and A. Flynn. (1993). Constructing the Countryside. London: UCL Press.

Marsden, T. (2006). Pathways in the sociology of rural knowledge, in P. Cloke, T. Marsden \& P. H. Mooney (eds.) Handbook of Rural Studies. London: SAGE.

Massey, D. (1999). Space-Time, 'Science' and the Relationship Between Physical Geography and Human Geography, Transactions of the Institute of British Geographers 24 (3): 261-276.

Massey, D. (1999). 'Space-Time, Science and the Relationship Between Physical Geography and Human Geography', Transactions of the Institute of British Geographers 24(3): 261-276.

Massey, D. (2004). 'Geographies of Responsibility', Geografiska Annaler: Series B 86(1): 5-18. 
Massey, D. (2005). For Space. London: SAGE.

Mayerfield Bell, M., Lloyd, S. E. \& Vatovec, C. (2010). Activating the countryside: Rural power, the power of the rural and the making of rural politics, Sociologia Ruralis 50 (3): 205-224.

Murdoch, J. (2005). Post-structuralist Geography: a guide to relational space. London: SAGE.

ONS (2012). Regional Profiles: Key Statistics - South East, August 2012.

http://www.ons.gov.uk/ons/rel/regional-trends/region-and-country-profiles/key-statistics-andprofiles---august-2012/key-statistics---south-east--august-2012.html, accessed 9/2/17.

ONS (2017). Standard Area Measurements (2016) for Administrative Areas in the United Kingdom. http://ons.maps.arcgis.com/home/item.html?id=a79de233ad254a6d9f76298e666abb2b, accessed 10/2/2017.

Oswald, R. F. \& Culton, L. S. (2003). Under the Rainbow: rural gay life and its relevance for family providers, Family Relations 52 (1): 72-81.

Parr, H., Philo, C. \& Burns, N. (2004). Social Geographies of Rural Mental Health: experiencing inclusions and exclusions, Transactions of the Institute of British Geographers 29 (4): 401-419.

Phillips, D. \& Williams, A. (1984). Rural Britain: a social geography. Ox: Blackwell.

Philo, C. (1992) Neglected Rural Geographies, Journal of Rural Studies 8 (2): 193-207.

Richardson, D. \& Monro, S. (2012). Sexuality, Equality and Diversity. NY: Palgrave Macmillan.

Roche, M. (2002). Rural Geography: searching rural geographies, Progress in Human Geography 26: 823-829.

Rose, G. (1993). Feminism and Geography: The Limits of Geographical Knowledge. Minneapolis: University of Minnesota Press.

Sibley, D. (2006). Inclusions/Exclusions in Rural Space, in P. Cloke, T. Marsden \& P. H. Mooney (eds.) Handbook of Rural Studies. London: Sage.

Smith, D. P. \& Holt, L. (2004). Lesbian Migrants in the Gentrified Valley and Other Geographies of Rural Gentrification, Journal of Rural Studies 21 (3): 313-322.

Smith, J.D. (1997). Working With Larger System - Rural Gays and Lesbians, in J.D. Smith \& R.J. Mancoske (eds.) Rural Gays and Lesbians - Building on the Strengths of Communities 13-21. New York: Haworth Press.

Soderstrom, M. (2010). A Single Queer Voice with Polyphonic Overtones - Elise Matthesen and the politics of subjectivity in the Twin Cities, in Twin Cities GLBT Oral History Project (eds.) Queer Twin Cities. Minneapolis: University of Minnesota Press.

Tongson, K. (2011). Relocations - Queer Suburban Imaginaries. New York: New York University Press.

University of Brighton (2016). On Our Doorsteps: A Cupp Initiative.

http://about.brighton.ac.uk/cupp/whatwedo/community-knowledge-exchange/on-our-

doorsteps.html, accessed 11/3/16. 
Valentine, G. (2002). Queer Bodies and the Production of Space, in S. Seidman and D. Richardson (eds.) The Handbook of Lesbian and Gay Studies 145-160. London: SAGE.

Valentine, G. \& Skelton, T. (2003). Finding Oneself, Losing Oneself: The Lesbian and Gay 'Scene' as a Paradoxical Space, International Journal of Urban and Regional Research 27 (4): 849-866.

Weston, K. (1995). Get Thee to a Big City: sexual imaginary and the great gay migration, GLQ 2 (3): 253-277.

Whatmore, S. (2002). Hybrid Geographies - natures, cultures, spaces. London: SAGE.

Whittier, D.K. (1997). Social Conflict Among "Gay" Men in a Small(er) Southern Town, in J.D. Smith \& R.J. Mancoske (eds.) Rural Gays and Lesbians - Building on the Strengths of Communities 53-72. New York: Haworth Press.

Woodward, R. \& Halfacree, K. (2002). Influences on Leadership and Local Power in Rural Britain, in K. Halfacree, I. Kovach \& R. Woodward (eds.) Leadership and Local Power in European Rural Development. Aldershot: Ashgate.

Woods, M. (2006). Redefining the Rural Question: the new politics of the rural and social policy, Social Policy \& Administration 40 (6): 579-595.

Woods, M. (2007). Engaging the Global Countryside: globalisation, hybridity and the reconstitution of rural place, Progress in Human Geography 31: 485-507.

Woods, M. (2011) Rural. Ox: Routledge.

Woods, M. (2012). New Directions in Rural Studies?, Journal of Rural Studies 25: 1-4. 